\title{
ИСПОЛЬЗОВАНИЕ ДИГИДРОКВЕРЦЕТИНА И АРАБИНОГАЛАКТАНА В ПИТАНИИ ПОРОСЯТ-ОТЬЁМЫШЕЙ
}

\author{
Л.А. Никанова \\ д.б.н., ведущий научный сотрудник отдела физиологии и биохи- \\ мии сельскохозяйственных животных \\ ФГБНУ «Федеральный научный центр животноводства - ВИЖ \\ имени академика Л.К. Эрнста», п. Дубровицы
}

При выращивании и откорме свиней часто используют кормовые антибиотики, гормоны роста, ферменты, антимикробные препараты, которые являются стимуляторами роста. Но при этом надо учитывать, что данные стимуляторы могут попасть в продукцию. Поэтому их использование в питании животных строго регламентировано, а применение антибиотиков в странах ЕС запрещено.

В последнее время предпочтение отдаётся использованию природных кормовых добавок, как основному фактору реализации биологического ресурса различных генотипов свиней.

Введение в рацион природных кормовых добавок (пребиотиков, пробиотиков, антиоксидантов и других препаратов) способствует повышению патогенетической резистентности и коррекции обменных процессов, обеспечивая повышение продуктивности и сохранности животных.

Повышение адаптивности и патогенетической резистентности поросят достигается использованием в питании свиней биологически активных кормовых добавок $[1,2,3]$. Особый интерес представляют кормовые добавки «Экостимул-2», в основе которых 70\% антиоксидант дигидрокверцетин и выполняющий роль пребиотика арабиногалактан. Обе кормовые добавки получают из древесины лиственницы даурской (Larix dahurica Turez) [1, 2].

Целью наших исследований являлось определение эффективности использования дигидрокверцетина и арабиногалактана в питании поросят-отъёмышей.

\section{Методика проведения исследований}

Исследования проведены на 2-х группах поросят-отъёмышей крупной белой породы. Поросята контрольной группы $(\mathrm{n}=10)$ получали общий рацион (комбикорма СK-4 и CK-5), поросятам опытной группы $(\mathrm{n}=10)$ в рацион вводили кормовые добавки «Экостимул-2» (дигидрокверцетин - из расчёта 50 мг/гол/день и арабиногалактан - из расчёта 5 г/гол/день). Продолжительность эксперимента 4 месяца.

Комбикорма СК-4 и СК-5 являются полнорационными и сбалансированными. 
Определение биохимических показателей сыворотки крови были проведены на автоматическом биохимическом анализаторе Chem Well (Awareness Technology, США).

\section{Результаты исследования}

Выращивание поросят в послеотъёмный период сопряжено с действием стрессовых моментов различного характера, а именно: отъём от маток, перегон в другое помещение, смена рациона кормления. Все это отражается на сохранности и интенсивности роста [4].

Введение в основной рацион кормовых добавок дигидрокверцетина и арабиногалактана ослабило действие стрессовых факторов среды, в результате по окончании эксперимента живая масса поросят в опытной группе была на 10,6\% выше, чем в контрольной. Совместное примене- ние дигидрокверцетина и арабиногалактана положительно сказалось и на сохранности поголовья, которая в опытной группе составила 100\%, в контрольной группе - $90 \%$.

Изучение клинико-физиологического состояния организма показало, что биохимические показатели сыворотки крови поросят контрольной и опытной групп различны, в то время как некоторые из них были схожи.

Количество лейкоцитов в крови поросят опытной группы было ниже на 8,0\%, а эритроцитов выше на 1,5\% по сравнению с этими показателями у поросят контрольной группы, что отразилось на содержании гемоглобина (был выше на 7,6\%) и гематокрита крови (выше на 6,4\%) (табл. 1).

Значение данных показателей свидетельствует о положительном влиянии кормовых доба-

Таблица 1 - Гематологические показатели крови поросят

\begin{tabular}{|l|c|c|c|c|}
\hline \multirow{2}{*}{\multicolumn{1}{|c|}{ Группа }} & \multicolumn{4}{|c|}{ Показатель } \\
\cline { 2 - 5 } & Лейкоциты, $\times 10^{9} / л$ & Эритроциты, $\times 10^{12} / л$ & Гемоглобин, г/л & Гематокрит, \% \\
\hline Контрольная & $19,22 \pm 2,18$ & $7,10 \pm 0,25$ & $112,7 \pm 4,88$ & $37,5 \pm 1,70$ \\
\hline Опытная & $17,69 \pm 1,27$ & $7,20 \pm 0,40$ & $121,3 \pm 4,57$ & $39,9 \pm 1,47$ \\
\hline
\end{tabular}

вок на состояние здоровья поросят, что способствовало реализации генетического потенциала в интенсивности роста.

Свободнорадикальное окисление липидов в организме могут вызвать технологические факторы, включая кормление. Исследование его состояния у поросят показало, что включение в питание поросят кормовых добавок позволило повысить антиоксидантную защиту организма и профилактировать развитие перекисного окисления липидов.

У поросят, получавших кормовые добавки, кислотное число, перекисное число и СЖК было ниже, чем у контрольных на 19,8, 20,5 и 19,7\% соответственно. С этими показателями корре- спондируется антиокислительная активность сыворотки крови, которая при применении кормовых добавок была выше, чем в контроле на 26,5 (табл. 2).

Важная роль в формировании продуктивного здоровья животных отводится функциональному состоянию печени, поскольку она занимает центральное место в обмене веществ.

В данных исследованиях дача кормовых добавок профилактировала гипербилирубинемию. В результате концентрация общего билирубина в плазме крови опытной группы поросят была ниже на 13,9\% (табл. 3).

Другими клиническими тестами функционального состояния печени являются активность

Таблица 2 - Состояние свободнорадикального окисления липидов и антиоксидантной защиты организма поросят

\begin{tabular}{|l|c|c|c|c|c|}
\hline \multirow{2}{*}{ Группа } & \multicolumn{5}{|c|}{ Показатель } \\
\cline { 2 - 6 } & $\begin{array}{c}\text { Кислотное } \\
\text { число КОН, мг/г }\end{array}$ & $\begin{array}{c}\text { Перекисное } \\
\text { число, \% }\end{array}$ & СЖК, \% & $\begin{array}{c}\text { Малоновый } \\
\text { диальдегид, мкM/л }\end{array}$ & $\begin{array}{c}\text { Антиокислительная } \\
\text { активность плазмы }\end{array}$ \\
\hline Контрольная & $3,64 \pm 0,02$ & $0,073 \pm 0,0$ & $1,83 \pm 0,01$ & $0,58 \pm 0,04$ & $1,36 \pm 0,02$ \\
\hline Опытная & $2,92 \pm 0,04$ & $0,058 \pm 0,0$ & $1,47 \pm 0,02$ & $0,40 \pm 0,02$ & $1,72 \pm 0,06$ \\
\hline
\end{tabular}


Таблица 3 - Функциональное состояние печени у поросят

\begin{tabular}{|l|c|c|}
\hline \multirow{2}{*}{\multicolumn{1}{|c|}{ Показатель }} & \multicolumn{2}{|c|}{ Группа } \\
\cline { 2 - 3 } & Контрольная & Опытная \\
\hline Билирубин общий, мкM/л & $3,81 \pm 0,67$ & $3,28 \pm 0,77$ \\
\hline АлАт, МЕ/л & $34,7 \pm 2,4$ & $28,2 \pm 5,1$ \\
\hline АсАТ, МЕ/л & $32,3 \pm 3,6$ & $26,6 \pm 2,4$ \\
\hline Отношение АсАТ/АлАТ & 0,93 & 0,94 \\
\hline Холестерин, ММ/л & $2,24 \pm 0,11$ & $3,32 \pm 0,17$ \\
\hline Глюкоза, мМ/л & $6,67 \pm 0,74$ & $5,44 \pm 0,83$ \\
\hline
\end{tabular}

аспартатаминотрансферазы (АсАТ) и аланинаминотрансферазы (АлАТ).

Активность АлАТ и АсАТ в сыворотке крови поросят опытной группы была ниже на 18,7 и $17,6 \%$, чем в контроле.

Содержание холестерина было выше на 1,8 мМ/л, чем в контроле, что характеризует состояние холестеринообразовательной функции печени.

Уровень глюкозы в крови у поросят был в пределах физиологической нормы и составлял 5,28-2,89 мМ/л, в то время как у поросят контрольной группы содержание глюкозы составляло 6,67 мМ/л, что выше физиологической нормы и может свидетельствовать о повышенной функции коры надпочечников и, в связи с этим, наличии глюконеогенеза $[5,6]$.

\section{Заключение}

Выращивание поросят в послеотъёмный период в условиях свинофермы связано с отрица- тельным влиянием технологических факторов на состояние здоровья, судя по клинико-биохимическим показателям крови, характеризуется лейкоцитозом, пониженным уровнем гемоглобина и гематокрита, развитием в организме свободнорадикального окисления липидов и неоглюкогенеза, пониженным уровнем функционального состояния печени и антиоксидантной защиты. В результате интенсивность роста на полнорационном комбикорме CK-4 и СК-5 у поросят-отъёмышей составила $411 \pm 25,4$ г при 90\% сохранности.

Введение в комбикорм кормовых добавок дигидрокверцетина и арабиногалактана позволило профилактировать вышеназванные нарушения в обмене веществ и создать условия в организме для усиления анаболических процессов и формирования продуктивного здоровья поросят при $100 \%$ сохранности. При этом проявилась специфика свойств кормовых добавок «Экостимул-2» и арабиногалактана в антиоксидантном и гепатопротекторном действии.

\section{Лumepamypa}

1. Фомичев, Ю.П. Дигидрокверцетин и арабиногалактан - природные биорегуляторы в жизнедеятельности человека и животных, применение в сельском хозяйстве и пищевой промышленности [Текст] / Ю.П. Фомичев, Л.А. Никанова, В.И. Дорожкин и др. - М.: «Научная библиотека», 2017. - 702 с.

2. Фомичев, Ю.П. Природные кормовые добавки «Экостимул» и «Арабиногалактан» в экологии, продуктивном использовании животных и птицы и комбикормовой промышленности [Текст]: практическое наставление / Ю.П. Фомичев, Л.А. Никанова, А.А. Торшков и др. - Дубровицы, 2010. - 88 с.

3. Шайдуллина, Р.Г. Использование пробиотиков, хитозана и дигидрокверцитина в рационах поросят [Текст] / Р.Г. Шайдуллина, Ю.П. Фомичев, Е.О. Фоломова и др. // Актуальные вопросы кормления сельскохозяйственных животных: материалы международ. науч.-практ. конф. - Дубровицы, 2007. - С. 321-325.

4. Максимов, В.И. Влияние БАД «Капилар» на адаптационные возможности организма [Текст] / В.И. Максимов, В.В. Пайтерова // Актуальные проблемы биологии в животноводстве: материалы V Международ. конф. - Боровск, ВНИФБиП, 2010. - С. 197-198.

5. Журавель, А.А. Патологическая физиология сельскохозяйственных животных [Текст] / А.А. Журавель, А.Г. Савойский, М.С. Григорян и др. - М.: Агропромиздат, 1985. - С. 304-305.

6. Комышников, В.С. Справочник по клинико-биохимическим исследованиям и лабораторной диагностике [Текст] / В.С. Комышников. - 3-е изд. - М.: МЕДпресс-информ», 2009. - С. 151. 


\section{References}

1. Fomichev, Yu.P. Digidrokvercetin i arabinogalaktan - prirodnye bioreguljatory $v$ zhiznedejatel'nosti cheloveka i zhivotnyh, primenenie $v$ sel'skom hozjajstve i pishhevoj promyshlennosti [Tekst] / Yu.P. Fomichev, L.A. Nikanova, V.I. Dorozhkin i dr. - M.: «Nauchnaja biblioteka», 2017. - $702 \mathrm{~s}$.

2. Fomichev, Yu.P. Prirodnye kormovye dobavki «Jekostimul» $\mathrm{i}$ «Arabinogalaktan» v jekologii, produktivnom ispol'zovanii zhivotnyh i pticy i kombikormovoj promyshlennosti [Tekst]: prakticheskoe nastavlenie / Yu.P. Fomichev, L.A. Nikanova, A.A. Torshkov i dr. - Dubrovicy, 2010. - 88 s.

3. Shajdullina, R.G. Ispol'zovanie probiotikov, hitozana i digidrokvercitina v racionah porosjat [Tekst] / R.G. Shajdullina, Yu.P. Fomichev, E.O. Folomova i dr. // Aktual'nye voprosy kormlenija sel'skohozjajstvennyh zhivotnyh: materialy mezhdunarod. nauch.-prakt. konf. - Dubrovicy, 2007. - S. 321-325.

4. Maksimov, V.I. Vlijanie BAD «Kapilar» na adaptacionnye vozmozhnosti organizma [Tekst] / V.I. Maksimov, V.V. Pajterova // Aktual'nye problemy biologii v zhivotnovodstve: materialy V Mezhdunarod. konf. - Borovsk, VNIFBiP, 2010. - S. 197-198.

5. Zhuravel', A.A. Patologicheskaja fiziologija sel'skohozjajstvennyh zhivotnyh [Tekst] / A.A. Zhuravel', A.G. Savojskij, M.S. Grigoryan i dr. - M.: Agropromizdat, 1985. - S. 304-305.

6. Komyshnikov, V.S. Spravochnik po kliniko-biohimicheskim issledovanijam i laboratornoj diagnostike [Tekst] / V.S. Komyshnikov. - 3-e izd. - M.: MEDpress-inform», 2009. - S. 151.

Работа выполнена при финансовой поддержке фундаментальных научных исследований ФАНО РФ, номер государственного учёта НИОКТР АААА-А18-118021590136-7.

\section{ОБЫЯВЛЕНИЕ}

\section{В издательстве ФГБОУ ВО Ярославская ГСХА в 2019 году вышла монография С.В.ГРОЗДИЛОВА}

\section{«СПРАВЕДЛИВОСТЬ: \\ ФИЛОСОФСКИЙ ДИСКУРС И СОЦИАЛЬНАЯ ПРАКТИКА»}

В монографии исследуется генезис и эволюция проблемы справедливости в социально-философской мысли, общественном сознании, системе социальных отношений. На основании диалектического, социокультурного подходов к познанию процессов и явлений общественной жизни осуществлена попытка обоснования природы справедливости как жизненно важного социального феномена: выявление его содержания и сущности как свойства, стороны общественных отношений. В работе показана социально-культурная, групповая и личностная значимость, роль справедливости в социальном процессе и исторической перспективе. Общефилософское исследование проблемы служит основанием для дальнейшего анализа существования и развития современного общества.

Монография имеет междисциплинарный характер: справедливость как сложное явление, характеризующее всю систему общественных отношений, выступает в ней объектом исследования с различных позиций социально-гуманитарного знания. Книга предназначена для самого широкого круга читателей, преподавателей и студентов гуманитарных факультетов высших и средних специальных учебных заведений.

УДК 636.2.084.1; ББК 45.3; ISВN 978-5-98914-206-4; 304 стр.

ПО ВОПРОСАМ ПРИОБРЕТЕНИЯ ОБРАЩАТЬСЯ ПО АДРЕСУ: 150042, г. Ярославль, Тутаевское шоссе, 58, ФГБОУ ВО Ярославская ГСХА e-mail: e.bogoslovskaya@yarcx.ru 